\title{
MENINGKATKAN KEMAMPUAN BELAJAR SISWA MENGENAL RANGKA MANUSIA PADA MATA PELAJARAN IPA MENGGUNAKAN MEDIA GAMBAR PADA SISWA KELAS IV SD 1 KRISTEN
}

\author{
Improving Students' Learning Ability To Recognize The Human Framework In Science \\ Courses Using Images In Class IV Students Of Sd 1 Kristen
}

\author{
Oleh: Arona \\ e-mail: aronagigin17@gmail.com
}

\begin{abstract}
ABSTRAK
Penelitian ini bertujuan untuk mengetahui pengaruh penggunaan alat peraga gambar terhadap upaya peningkatan kemampuan belajar siswa mengenal rangka manusia dalam mata pelajaran IPA Pada Siswa Kelas IV SD 1 Kristen, penelitian ini bersifat deskriptif artinya mencoba memaparkan hasil penelitian dari hasil pengolahan data yang ada.

Penelitian ini melibatkan 26 siswa kelas IV SD 1 Kristen yang dilaksanakan melalui 2 siklus. Siklus I dan siklus Il menggunakan pokok bahasan fungsi rangka manusia dan perawatannya, masing-masing siklus mengikuti tahap-tahap model Kemmis dan Mc Taggart, yaitu (1) penyusunan rencana, (2) pelaksanaan tindakan, (3) observasi tindakan, (4) retleksi tindakan yang akan dilaksanakan. Data diperoleh melalui tes hasil belajar, observasi, dan dianalisis menggunakan teknik deskriptif.

Hasil analisis data menunjukkan bahwa kemampuan menggunakan alai peraga gambar mencapai kualifikasi baik atau (70 - $90 \%)$ dan kriteria ketuntasan belajar. Respon siswa terhadap menggunakan alat peraga gambar dapat diterima dengan baik oleh siswa. Hasil belajar siswa mengikuti Pre-Tes pada siklus I memiliki rata-rata 63,62, sedangkan pada siklus II memiliki rata-rata 75,08. Hasil belajar siswa mengikuti Pos-Tes pada siklus I memiliki ratarata 80,54, sedangkan pada siklus II memiliki rata-rata 89,69 Meningkatkan hasil belajar yang diperoleh siswa tersebut didukung pula oleh data hasil. Dan hasil tersebut dapat disimpulkan bahwa menggunakan alat peraga gambar dapat meningkatkan kemampuan belajar siswa mengenal rangka manusia dalam mata pelajaran IPA Pada Siswa Kelas IV SD 1 Kristen.
\end{abstract}

Kata Kunci : Kemampuan Belajar, Meja Gambar, Rangka Manusia.

\section{ABSTRACT}

This study aims to determine the effect of using picture props on efforts to increase students' learning abilities to recognize the human skeleton in science subjects in Grade IV students of SD 1 Kristen, this research is descriptive, meaning that it tries to explain the results of research from the results of existing data processing.

This study involved 26 fourth grade students of SD 1 Kristen which was carried out through 2 cycles. Cycle I and cycle II used the subject of the function of the human skeleton and its maintenance, each cycle following the stages of the Kemmis and Mc Taggart model, namely (1) planning, (2) implementing actions, (3) observing actions, (4) reflection of the actions to be carried out. Data were obtained through learning outcomes tests, observations, and were analyzed using descriptive techniques.

The results of data analysis showed that the ability to use the visual aids achieved good qualifications or (70 - 90\%) and the criteria for learning completeness. Student responses to using picture props were well received by students. Student learning outcomes taking the Pre- 
Test in the first cycle had an average of 63.62, while in the second cycle had an average of 75.08. Student learning outcomes following the Post-Test in the first cycle had an average of 80.54, while in the second cycle it had an average of 89.69. Increasing the learning outcomes obtained by these students was also supported by the result data. And from these results it can be concluded that using picture props can improve students' learning abilities to recognize the human skeleton in science subjects in Grade IV students of SD 1 Kristen.

Keywords : Learning Ability, Drawing Table, Human Skeleton.

\section{PENDAHULUAN}

Kemampuan siswa dalam mengikuti pelajaran selalu berbeda-beda hal ini disebabkan oleh karena kondisi individual anak juga tidak sama antara yang satu dengan yang lainnya. Perbedaan dimaksud tentu akan membawa pengaruh yang cukup besar dalam kemampuan mereka mengikuti pelajaran yang disampaikan oleh guru di kelas. Perbedaan kemampuan tersebut antara lain meliputi ; kemampuan IQ, kemampuan ekonomi keluarga, kemampuan jiwa, kemampuan sosial, kemampuan fisik anak dan lain-lain. Pada saat mengikuti proses belajar mengajar di kelas masing ᄀ-masing, anak sering menghadapi kesulitan, artinya masih banyak kendala-kendala yang dihadapi, terutama yang berkaitan dengan faktor guru, faktor metode/pendekatan, faktor sarana atau alat pelajaran, faktor siswa, kondisi tempat belajar dan lain-lain. Namun faktor yang sangat dominan sekali adalah faktor kemampuan belajar siswa itu sendiri yang lebih besar dalam mengikuti seluruh proses pembelajaran yang disampaikan guru di kelas. Tanpa adanya motivasi siswa dalam mengikuti pembelajaran di kelas, maka selain bagi mereka untuk bisa meraih suatu prestasi belajar yang memadai Untuk dapat meningkatkan kemampuan belajar siswa dimaksud, tentu tidak luput dari faktor ketepatan guru dalam memilih metode mengajar yang tepat.

Ketepatan memilih metode mengajar tersebut bukan suatu hal yang mudah, akan tetapi membutuhkan pemikiran, pengetahuan, pengalaman, dan beberapa langkah lainnya yang dipandang, dapat memberikan masukan dan arahkan kepada guru. B3eranjak dari pengalaman saya sebagai guru selama ini mengajar di tingkat sekolah dasar, telah menemukan beberapa hal yang berkaitan dengan kurangnya kemampuan siswa dalam menyerap pelajaran dari guru di sekolah, yakni terlihat bahwa sebahagian besar siswa kelas IV SD 1 Kristen, ini yang mendapat nilai rendah, yakni rata-rata sebesar $57,71 \%$ siswa mendapat nilai dibawah 6 , dan sebahagian kecil saja siswa yang mendapat nilai diatas 6 yakni sebesar $42,29{ }^{\circ}$ o saja. Jadi kondisi belajar seperti ini tentu sangat menyedihkan sekali untuk mata pelajaran sains terutama dalam proses belajar sains yang dipandang cukup penting bagi bekal pengetahuan dan pengalaman siswa di masyarakat.

Faktor penyebab permasalahan dimaksud, diindikasikan oleh karena pendekatan pembelajaran yang digunakan guru selama ini kurang begitu tepat dan cocok dengan kondisi siswa, dimana kegiatan belajar mengajarnya disajikan dalam bentuk ceramah melulu di dalam kelas, tanpa ada selingan kegiatan lainnya, misalnva penampakkan gambar-gambar atau foto-foto yang berhubungan langsung dengan kegiatan mengenal rangka manusia sehingga bisa menumbuhkan semangat siswa untuk menikuti pelajaran dengan baik di kelas. 
kecendrungan yang sering terlihat di pihak siswa adalah mereka menjadi malas, kurang rajin, kurang memperhatikan penjelasan guru, berbicara dalam kelas, kurang antusias ketika pelajaran berlangsung, rendahnya respon dan umpan balik dan siswa terhadap pertanyaan dan penjelasan dan guru, pemusatan perhatian siswa sangat kurang dan lain-lain, sehingga akhirnya sulit menerima pelajaran yang disampaikan gurunya, karena proses pembelajaran yang dilakukan saat itu cendrung menggunakan metode ceramah melulu. Jadi dalam penyajian konsep pengajaran IPA di sekolah dasar selama ini masih kecendrungannya menekankan pada konsep-konsep yang terdapat di dalam buku saja, akan tetapi kurang banyak menampilkan beberapa peragaan, seperti gambar-gambar, foto-foto, dan berbagai bentuk tampilan lainnya kepada siswa, sehingga menyebabkan siswa dapat dengan mudah mengenal apa yang akan diajarkan guru. Disamping itu pula bahwa konsep pengajaran sains yang diajarkan kepada siswa di sekolah dasar selama ini cenderung bersifat hafalan dan kurang mementingkan proses pengenalan terhadap sesuatu yam, dipandang lebih berharga dan lebih bernilai tinggi. Jadi proses pengenalan terhadap pokok bahasan dalam mata pelajaran sains tersebut oleh siswa kurang diperhatikan, pada hal konsep pengenalan tersebut baru bisa berkembang apabila guru mampu membawa anak didik ke dalam kegiatan nyata yang bisa dilihat olehnya, yakni dengan melihat gambargambar atau foto-foto yang menghubungkan dengan topik bahasan guru di sekolah sehingga mampu menciptakan suatu kontek pembelajaran-yang cukup bermakna. Jika hal mum dapat dilaksanakan oleh guru dengan baik, maka diharapkan mampu membawa siswa yang lebih bermakna dalam belajar sains, yakni mampu mendapatkan konsep

yang, memberikan relevansi yang cukup besar dalam kehidupan sehari-hari.

Berdasarkan gejala diatas terlihat nyata pada saat kegiatan pembelajaran berlangsung, dimana guru menyajikan pelajaran di kelas sambil memperlihatkan gambar-gambar atau foto-foto yang ada keterkaitan dengan topik materi bahasan itu. Maka oleh sebab itu kendala ini tidak bisa dibiarkan berlarut-larut, lama kelamaan tentu bisa mempengaruhi perkembangan belajar siswa selanjutnya dan juga berpengaruh terhadap pengembangan kreativitas dan semangat kerja yang positif untuk waktuwaktu yang akan datang. Sedangkan di suatu sisi bahwa siswa itu hams mampu berkembang dengan penuh kreasi dan imajinasi yang cukup tinggi sebagai bekal pengetahuan dan pengalaman bagi dirinya dalam rangka berintereaksi di masyarakat. Namun, di lain pihak masyarakat juga membutuhkan sumber daya manusia yang handal dan mampu bekerja secara mandiri. Penggunaan alat peraga gambar dan foto-foto dalam penyajian materi pelajaran sains tersebut bagi siswa dimaksud merupakan suatu pendekatan baru yang diharapkan mampu mengatasi permasalahan belajar yang dihadapi oleh siswa di sekolah dasar selama ini. Dalam rangka memilih dan menggunakan alat peraga di dalam proses belajar bukan suatu hal sulit, namun penggunaan alat peraga juga sering kali diabaikan oleh guru-guru, pada hal media itu adalah merupakan suatu jernbatan penghubung yang amat penting dalam pembelajaran. Penggunaan media gambar atau foto seperti ini diharapkan akan lebih membantu kemampuan anak didik terutama di dalam usaha membangkitkan rangsangan panca indra si anak, terutama dalam melihat obyek persoalan yang akan disampaikan kepada mereka dalam belajar. Hal ini sebagai 
mana yang diungkapkan berikut ini bahwa : "Simbol-simbol tersebut perlu dipahami benar artinya agar proses penyampaian pesan dapat berhasil dan efisien". (Dr. Arief S. Sadiman, M.Sc, Drs. R. Rahardjo, M.Sc, Anung Haryono, M.Sc, C.A.S., Rahard.lito, 2007. Hal. 28). Berdasarkan uraian-uraian yang telah dipaparkan di dalam latar belakang dan rumusan masalah diatas, maka dapat dirumuskan tujuan dalam penelitian ini. Adapun

tujuan utama melakukan kegiatan penelitian ini adalah sebagai berikut : Untuk mengetahui pengaruh penggunaan alat peraga gambar terhadap upaya peningkatan kemampuan belajar siswa mengenal rangka manusia dalam mata pelajaran IPA Pada Siswa kelas IV SD 1 Kristen. Adapun perkembangan media dewasa ini dalam kegiatan pembelajaran tidak saja berfungsi sebagai alat bantu mengajar, akan tetapi lebih sari itu dapat dipandang sebagai obyek dan sarana untuk memberikan pengalaman kongkrit pada peserta didik. Salah satu ciri media pembelajaran adalah bahwa media mengandung dan membawa pesan atau informasi kepada penerima yaitu siswa. Sebagian media dapat mengolah pesan dan respons siswa sehingga media itu sering disebut media interaktif. Pesan dan infiormasi yang dibawa oleh media bisa berupa pesan yang sederhana dan bisa pula pesan van,, anrat kompleks Akan tetapi, yang terpenting adalah media itu disiapkan untuk memenuhi kebutuhan belajar dan kemampuan siswa serta siswa dapat aktif berpartisipasi dalam proses belajar mengajar oleh karena itu, perlu dirancang dan dikembangkan lingkungan pembelalaran yang interaktif yang dapat menjawab dan memenuhi kebutuhan belajar perorangan dengan menyiapkan kegiatan pembelajaran dengan medianva yang efektif guna menjamin terjadinya pembelajaran. media pembelajaran adalah alat, metode dan teknik yang digunakan dalam rangka lebih mengefektifkan komunikasi dan interaksi antara guru dan siswa dalam proses pembelajaran di sekolah (Oemar Hamalik. 1989) Perkembangan ilmu pengetahuan dan teknologi makin mendorong upaya-upaya pembaharuan dalam pemanfaatan hasil-hasil teknologi dalam proses belajar mengajar. Para guru dituntut agar mampu menggunakan alat-alat yang dapat disediakan oleh sekolah, dan tidak tertutup kemungkinan bahwa alatalat tersebut sesuai perkembangan dan tuntutan zaman.

Guru sekurang-kurangnya dapat menggunakan alat yang murah dan efisien yang meskipun sederhana dan bersahaja tetapi merupakan keharusan dalam upaya mencapai tujuan pengajaran yang diharapkan.

\section{Mengenal Rangka Manusia}

Pernahkah kamu melihat orang bongkok atau berjalan dengan badan miring? Kondisi badan yang demikian itu adalah kondisi badan yang tidak normal. Hal itu bisa terjadi bermula dari kebiasaan memposisikan badan ketika berbaring, duduk, dan berdiri yang tidak benar. Lihatlah berbagai contoh posisi duduk di bawah ini. Pilihlah gambar mana yang menunjukkan posisi duduk yang benar!

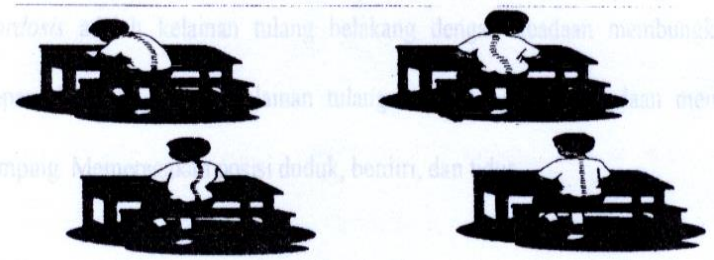

2. Penyakit Pada Rangka manusia

Penyakit pada rangka manusia disebabkan oleh berbagai faktor. Faktor-faktor yang dapat menyebabkan timbulnya berbagai penyakit pada rangka manusia antara lain kekurangan gizi, keturunan, kecelakaan, dan kebiasaan buruk seperti contoh sikap badan 
yang tertera pada gambar-gambar di atas. Berikut beberapa penyakit dan gangguan pada tulang.

1) Penyakit rakhitis.

Penyakit rakhitis adalah penyakit pada tulang di mana keadaan tulang tidak keras sehingga tubuh tidak normal atau membengkok. Misalnya, kedua kaki mengarah membentuk huruf $\mathrm{O}$ atau huruf $\mathrm{X}$ hal ini disebabkan karena kekurangan vitamin D.

2) Penyakit osteoporosis.

Penyakit osteoporosis adalah penyakit dimana keadaan tulang dan penyakit ini biasanya dialami oleh orang tua

3) Fififosis adalah, tulang belakang dengan keadaan kebelakang

\section{4) Lordosis}

Lordosis adalah kelainan tulang belakang dengan keadaan membungkuk ke depan. Lordosis adalah kelainan tulang belakang dengan keadaan membelok samping. Memeragakan posisi duduk, berdiri, dan tidur.

3. Struktur Rangka Manusia dan Fungsinya

1) Bagian Rangka

Rangka manusia terdiri atas susunan tulang-tulang yang saling berkaitan sehingga membentuk tubuh. Berdasarkan bentuknya, tulang digolongkan menjadi tiga macam.

a. Tulang pipa, contohnya tulang paha, tulang betis, dan tulang kering.

b. Tulang pipih, contohnya tulang rusuk, tulang rusuk, tulang belikat, dan tulang tengkorak

c. Tulang pendek, contohnya tulang pangkal tangan, tulang pangkal kaki, dan tulang rusuk-rusuk tulang belakang.

Rangka manusia dibagi menjadi tiga bagian, yaitu rangka kepala, rangka badan, dan rangka anggota gerak. Perhatikan gambar rangka manusia berikut ini:

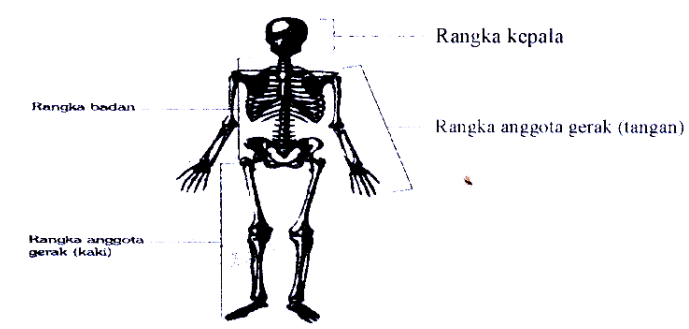

Sumber : Ensiklopedi Saing untuk Pelajar

Rangka kepala (tengkorak) ranoka kepala manusia terdiri atas tulang-tulang pipih yang saling mengait sehingga membentuk tempurung yang kokoh. Jumlah tulang pada tengkorak kurang lebih 30 buah.

Tulang kepala terdiri atas sambungan tulang-tulang. Rangka kepala terdiri atas dua sisi, yaitu tulang tengkorak bagian muka (wajah) dan tulang tengkorak bagian belakang (tempurung). Rangka badan terdiri atas tulang belakang, tulang dada, rusuk, tulang gelang bahu, dan tulang panggul.

Bagian anggota gerak rangka anggota gerak terdiri dari tulang-tulang pipih yang beruas-ruas Tulang anggota gerak dibagi menjadi dua bagian, yaitu tulang anggota gerak atas (tulang tangan) dan tulang anggota gerak bawah (tulang kaki). Perhatikan gambar di bawah ini.

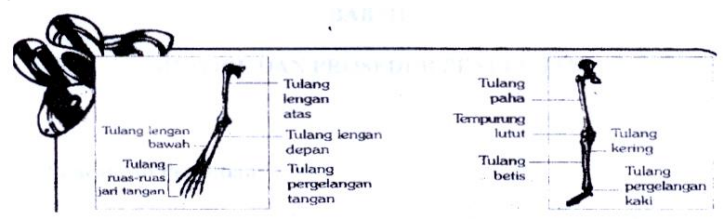

2) Fungsi Rangka

Rangka memiliki berbagai macam fungsi, antara lain sebagai berikut :

(1) Menguatkan tubuh.

(2) Melindungi organ-organ lunak dalam tubuh.

(3) Sebagai tempat menempelnya otot-otot.

(4) Sebagai pembentuk badan atau tubuh.

(5) Untuk memudahkan gerak.

Dengan adanya rangka, tubuh manusia menjadi kuat. Hal ini disebabkan adanya 
tulang-tulang penyusun rangka Tubuh manusia yang tidak mempunyai rangka tidak dapat berdiri tegak dan tidak kuat (lemas). Di dalam tubuh manusia terdapat organ-organ yang lunak. Dengan rangka, organ-organ seperti otak, paru-paru, jantung, hati, dart sebagainya akan terlindung dari benturan maupun tekanan dart luar.

Rangka manusia terdiri dari tulangtulang. Kesehatan tulang berarti kesehatan rangka tubuh. Agar rangka tubuh tetap sehat maka harus dijaga kesehatan tulang beberapa usaha agar rangka tubuh tetap sehat adalah sebagai berikut

(1) Membiasakan mengkonsumsi makanan yang bergizi.

(2) Olahraga secara teratur di pagi hari

(3) Membiasakan mengatur sikap tubuh yang baik untuk kesehatan

(4) Segera periksa ke dokter dan berobat jika terasa sakit.

\section{METODE PENELITIAN}

Kegiatan penelitian ini dilaksanakan menurut pendekatan kualitatif dengan metode model Kemmis dan Mc Taggart (Depdikbud :1999) yang dalam pelaksanaannya mencakup empat langkah, yaitu : 1) perencanaan tindakan; 2) pelaksanaan tindakan; 3) observasi tindakan; 4) refleksi atas tindakan yang dilaksanakan. Dalam pelaksanaan kegiatan pembelajaran, mengobservasi aktivitas guru dan murid pada saat pelaksanaan pembelajaran berlangsung, memberikan test pada awal siklus dan pada akhir seluruh siklus. Sesuai dengan materi kegiatan pembelajaran terdiri dari tiga (3) siklus. Tempat pelaksanaan penelitian adalah pada SD 1 Kristen. Kegiatan pengamatan dilakukan untuk mengetahui aktivitas guru dan murid dalam proses pembelajaran dengan menggunakan alat peraga gambar. Pengamatan dilakukan oleh guru bidan, studi
IPA yang mengajar di kelas IV oleh siswa dan salah seorang teman sejawat yaitu guru satu sekolah dengan peneliti. Pengamat dilakukan selama proses pembelajaran berlangsung Pengolahan data meliputi memberi skor pada hasil jawaban siswa, mendeskripsikan data yang, diperoleh dari hasi tes, pengamatan. dan wawancara.

\section{HASIL PENELITIAN DAN PEMBAHASAN}

Penelitian tindakan kelas ini dilaksanakan di kelas IV SD 1 Kristen, datadata yang di uraikan di dalam penelitian ini, yang pertama adalah data tentang hasil belajar siswa tentang materi pada pokok bahasan rangka manusia, sebelum diadakan tindakan atau data awal, kemudian pengambilan data hasil belajar siklus I, kemudian pengambilan data hasil belajar pada siklus II pada materi mengenal rangka manusia, selanjutnya data yang diuraikan adalah hasil kemampuan guru mengajar pada siklus satu dan siklus dua dan hasil aktivitas belajar siswa pada siklus I dan siklus dua.

\section{Siklus I}

Hasil ketuntasan belajar siswa kelas IV SD 1 Kristen, pada pokok bahasan mengenal rangka manusia dengan menggunakan media gambar diperoleh ketuntasan pembelajaran tingkat ketercapaian sebesar $63,62 \%$ dan hasil Pre-Tes dan Pre-Tes dan 75,08\% dan hasil Pos-Tes. Hal ini menunjukkan bahwa pada saat Pre-Test nampaknya penguasaan pembelajaran masih belum terpenuhi, namun setelah kegiatan pembelajaran dilaksanakan baru ada perubahan, maka dengan demikian penggunaan media gambar baik dalam rangka menyajikan pokok bahasan mengenal rangka manusia dalam mata pelajaran IPA di sekolah dasar.

Data distribusi nilai ketuntasan belajar pada siklus I dapat dilihat tingkat ketuntasan 
belajar dari hasil Pre-Tes pada pokok bahasan mengenal rangka manusia dengan menggunakan media gambar yaitu sebesar $63,62 \%$ dan yang tidak tuntas sebesar $36,38 \%$. Sedangkan dari hasil Pos-Tes pada pokok bahasan ciri-ciri mahluk hidup dengan menggunakan pendekatan individual adalah sebesar $75,08^{\circ} \mathrm{o}$ dan yang tidak tuntas adalah sebesar 24,92\%. Adapun indicator keberhasilan dari siklus I adalah sebagai berikut : siswa berminat terhadap pelajaran jawabannva: cukup baik. Perhatian siswa terhadap kegiatan pembelajaran, jawabannva cukup baik Siswa aktif untuk memberikan kritik dan saran, jawabannya cukup baik. Berdasarkan hasil observasi terhadap Penelitian Tindakan Kelas (PTK) yang dilaksanakan di kelas IV SD 1 Kristen pada siklus I tersebut, observer mengambil kesimpulan bahwa hasil PTK pada siklus I sudah dapat dikatakan mencapai sasaran, tetapi masih belum sesuai dengan harapan, karena masih ada jawaban yang kategori kurang baik. Perlu adanya langkah $\neg$-langkah perbaikan pada siklus II sesuai dengan beberapa indikator yang belum dikategorikan sangat baik atau masih ada kategori jawaban yang masih kurang baik, dan kategori tersebut diusahakan dapat diperbaiki pada siklus ke II.

\section{Siklus II}

Hasil belajar siswa kelas IV SD 1 Kristen pada pokok bahasan mengenal rangka manusia dengan menggunakan media gambar diperoleh nilai ketuntasan belajar sebesar $80,54 \%$ dan tidak tuntas sebesar 19,46\% dari hasil Pre-Tes dan ketuntasan belajar dari hasil Pos-Test sebesar $89.69 \%$ dan tidak tuntas sebesar $10.31 \%$.

Dari data distribusi nilai ketuntasan belajar pada siklus II tersebut diatas. dapat dilihat tingkat ketuntasan belajar dan hasil Pre-Tes pada pokok bahasan Mengenal rangka manusia dengan menggunakan media gambar yaitu sebesar $80,54 \%$ dan vane tidak tuntas sebesar 19,46\%', sedangkan dan hasil Pos-Tes pada pokok bahasan Mengenal rangka manusia dengan menggunakan media gambar yang tuntas adalah sebesar 89,69\% dan yang tidak tuntas adalah sebesar 10,31\%. Adapun indikator keberhasilan dari siklus II ini adalah sebagai berikut :

1) Siswa berminat terhadap pelajaran, jawabannva - sangat baik

2) Siswa mampu untuk memahami pelajaran, jawabannya - sangat baik.

3) Siswa mampu untuk memperhatikan proses pelajaran, jawabannya : sangat baik

4) Siswa aktif untuk bertanya dan memberikan pendapat, jawabannya : sangat baik.

5) Siswa aktif untuk memberikan kritik dan saran, jawabannya sangat baik

6) Siswa mampu mengerjakan soal latihan dengan baik, jawabannya : sangat baik

Dari hasil penelitian tindakan kelas terhadap kegiatan pembelajaran dengan menggunakan media gambar pada pokok bahasan mengenal rangka manusia di kelas IV SD 1 Kristen, ternyata dapat meningkatkan kemampuan siswa terhadap pembelajaran IPA pada pokok bahasan mengenal rangka manusia. Hal ini dapat dilihat dari hasil observasi (pengamatan) dan analisa terhadap beberapa indikator keberhasilan yang telah dicapai dalam kegiatan penelitian tindakan kelas kali ini. Adapun indikator keberhasilan yang dimaksud adalah sebagai mana yang diuraikan berikut ini :

1) Siswa sangat berminat terhadap pelajaran.

2) Siswa sangat mampu memahami materi pelajaran.

3) Siswa sangat mampu untuk memperhatikan proses belajar mengajar.

4) Siswa sangat aktif dalam bertanya 
5) Siswa sangat aktif dalam memberikan kritik dan saran-saran.

6) Siswa sangat mampu dalam mengerjakan soal-soal latihan

7) Siswa sangat mampu dalam menjalin kerjasama

\section{KESIMPULAN}

Berdasarkan hasil penelitian tindakan kelas dilakukan oleh peneliti di kelas IV SD 1 Kristen kali ini, maka dapat disimpulkan sebagai mana dalam uraian berikut ini :

(1)Peningkatan kemampuan siswa Kelas kelas IV SD 1 Kristen dalam mengajar IPA pada pokok bahasan mengenal rangka manusia dapat dilakukan melalui penggunaan media gambar

(2)Hasil observasi memperlihatkan bahwa terjadi peningkatan kemampuan siswa kelas IV SD 1 Kristen dalam mengajar IPA dapat dilakukan melalui penggunaan media gambar yang mana pada siklus I hanya mencapai angka rata-rata $63,62 \%$ saja, naik pada siklus ke II menjadi $89,69 \%$.

(3)Hasil penelitian ini menunjukkan bahwa pembelajaran dengan menggunakan media gambar dipandang cocok sebagai salah satu upaya untuk meningkatkan kemampuan siswa, menyenangkan siswa sehingga siswa antusias mengikuti pembelajaran, siswa lebih mudah memahami materi yang ; diberikan, khususnya pada pokok bahasan mengenal rangka manusia, yang banyak menampilkan berbagai media gambar dalam mengajarkan topik bahasan rangka manusia kepada para siswa, hal inilah yang menyebabkan siswa menjadi terdorong untuk memperhatikan pembelajaran. Pembelajaran dengan men8gunakan media gambar ini dapat pula meningkatkan hasil belajar siswa dalam hal pemahaman siswa tentang materi, daya ingat siswa, dan keaktifan siswa dalam belajar. Dengan demikian pembelajaran dapat dikategorikan tercapai mampu memenuhi harapan. Oleh karena itu, penggunaan media gambar ini dapat digunakan sebagai teknik pembelajaran dalam proses belajar mengajar IPA di sekolah dasar.

(4)Tingkat Ketercapaian (TK) dan tingkat ketuntasan belajar siswa setelah diajarkan dengan menggunakan media gambar mi mampu memperoleh nilai Pos-tes pada siklus I selalu meningkat untuk Siklus II, pokok bahasan mengenal rangka manusia, dapat dilihat tingkat ketuntasan belajar mengalami peningkatan dimana pada siklus I sebesar 75,08\% dan pada siklus II sebesar $89,69 \%$.

\section{DAFTAR PUSTAKA}

Dalyono, M. 1997 Psikologi pendidikan Jakarta Rineka Cipta.

Departemen Pendidikan dan kebudayaan. 1999. Penelitian Tindakan Kelas. Jakarta : Departemen Pendidikan dan Kebudayaan

Departemen Pendidikan Naswnal 2005. Materi Pelatihan terintegrasi Ilmu Pengetahuan Alam. . Jakarta Departemen Pendidikan Nasional

Direktorat Pendidikan Menengah Umum. 2003, Pedoman pembelajaran Tuntas (Mastery Learning)Jakarta Direktorat Pendidikan Menengah Umum.

FKIP UNPAR. 2007. Pedoman Penulisan proposal dan Skripsi. Palangka Raya FKIP UNPAR

Kardi, S. 1997.Model Pembelajaran Langsung. Surabaya : IKIP Surabaya

Naparin, Akhmad. 2004. Upaya Memaksimalkan pemahaman Konsep Makh;uk Hidup Murid Kelas VI SD Negeri Sungai Miai 7 Banjarmasin dengan Menggunakan Pendekatan 
Lingkungan. Banjarmasin : Lembaga

Penelitian Universitas Lambung

Mangkurat

Nasution, S. 2004. Didaktik Asas-asas Mengajar. Jakarta : Buki Aksara

Nuryani, R. 2005. Strategi Belajar Mengajar Biologi. Malang : Universitas Negeri Malang.

Permadi, Ade S dan Febriana Mentari. 2020. Penerapan Media Pembelajaran Powerpoint Untuk Meningkatkan Hasil Belajar Mata Pelajaran IPA Di SMP Negeri 1 Kahayan Kuala. Bitnet: Jurnal Pendidikan Teknologi Informasi. 5:1(55-62).

Piter, Y. 2001,Kompetensi Guru dalam pengelolaan Kelas, Buletin pelangi Pendidikan. 2000. Volume ; Nomor I : 23

Sadiman, Arief S., Dr. MSc, Rahardjo, R. Drs , M.Sc, Haryono, Anun", M.Sc, CAS., Rahardjito, Media Pendidikan Pengertian Pengembangan dan Pemanfaatannya, Penerbit PT Raja Grafindo Persada, Jakarta, 2007.

Sadirman, 2001 Interaksi dan Motivasi Belajar Mengajar. Jakarta Raja Grafindo Persada

Seiawan, Muhammad Andi dan Agung Riadin. 2021. Meningkatkan Hasil Belajar Ipa Peserta Didik Dengan Bimbingan Teman Sebaya Berbasis Nilai-Nilai Huma Betang. JBKI (Jurnal Bimbingan Konseling Indonesia). 6:1(27-31).

Slameto. 1995. Belajar dan Faktor-Faktor yang Mempengaruhinya, Jakarta Rineka Cipta.

Sudjana, N 1994. Penilaian Proses Hasil
Belajar Mengajar. Bandung: Remaja Rosdakarya.

Usman U. 1995. Menjadi Guru Profesional:

Edisi Kedua : Remaja Rosdakarva. 